\title{
ANALISIS DISTRIBUSI FASIES GUNUNG MERAPI DI KECAMATAN SELO UNTUK IDENTIFIKASI JENIS BAHAYA ERUPSI
}

\author{
Oleh: \\ Edi Widodo \\ Supporting Staff Dinas Lingkungan Hidup Kabupaten Magelang \\ ediwidodo15@gmail.com
}

\begin{abstract}
Abstrak
Penelitian ini bertujuan mengetahui: (1) distribusi fasies Gunung Merapi yang terdapat di Kecamatan Selo, (2) jenis bahaya erupsi di Kecamatan Selo berdasarkan distribusi fasies gunungapi. Populasi dalam penelitian ini adalah adalah seluruh medan di Kecamatan Selo dengan populasi sasaran yaitu kondisi fisik lahan yang pernah terlanda dan kondisi fisik lahan yang diduga mungkin terlanda bencana erupsi. Sampel diambil secara purposive dengan pertimbangan satuan morfologi dan singkapan batuan. Data dikumpulkan melalui wawancara, observasi, dokumentasi dan interpretasi citra. Analisis data dilakukan secara deskriptif. Hasil penelitian menunjukkan (1) jenis fasies Gunung Merapi meliputi fasies sentral, piroksimal, dan medial. Fasies sentral meliputi wilayah kepundan gunungapi, fasies piroksimal meliputi kerucut gunungapi, sedangkan fasies medial meliputi lereng dan kaki gunungapi yang banyak ditempati oleh masyarakat. (2) jenis bahaya erupsi pada fasies sentral dan piroksimal berupa aliran lava, aliran piroklastik, dan jatuhan piroklastik, sedangkan pada fasies medial berupa aliran piroklastik dan lahar. Informasi jenis bahaya berdasarkan ini bermanfaat dalam upaya mitigasi bencana.
\end{abstract}

Kata kunci: Fasies Gunungapi, Bahaya Erupsi, Gunung Merapi, Kecamatan Selo

\begin{abstract}
This research aims at investigating (1) the distribution of Mount Merapi facies in Selo Subdistrict, (2) the type of eruption hazard in Selo Subdistrict based on facies distribution. The population in this research includes all terrains in Selo subdistrict targeted to the physical condition of the land that has ever been hit by the eruption and the physical condition of the land that is potentially to be hit by the volcano eruption. Samples were taken purposively by considering the morphological unit and rock outcrop. Data were collected through interviews, observations, documentations and image interpretations. The data analysis was performed using a descriptive analysis technique. The results show that: (1) the type of Mount Merapi facies include central, pyroximal, and medial. The central facies cover the crater, the pyroximal includes volcanic cone, while the medial facies include volcanic slopes and volcanic foot which are widely occupied by the community. (2) the type of eruption hazard in the central and pyroximal facies consists of lava flows, pyroclastic flows, and pyroclastic falls, whereas the medial facies are pyroclastic flows and lava.
\end{abstract}

Keywords: Volcanic Facies, Eruption Hazard, Mount Merapi, Selo Subdistrict 


\section{PENDAHULUAN}

Indonesia merupakan negara kepulauan yang memiliki banyak Gunungapi aktif. Hal disebabkan oleh letak Indonesia yang merupakan tempat bertemunya lempeng tektonik besar diantaranya yaitu Lempeng Indo-Australia dan Lempeng Eurasia. Pada pertemuan lempeng ini, Lempeng Indo-Australia menyusup ke bawah Lempeng Eurasia dan terbentuklah rangkaian gunungapi yang membujur dari Pulau Sumatera, Jawa, Sampai pulau-pulau timur Indonesia. Gunung Merapi merupakan salah satu gunungapi yang terbentuk dari proses ini. Sampai saat ini aktivitas vulkanisme Gunung Merapi masih tetap berlangsung sehingga sering disebut sebagai salah satu vulkan teraktif di dunia (Sutikno dkk, 2007: 3).

Kecamatan Selo di Kabupaten Boyolali termasuk daerah dengan jumlah penduduk besar yaitu 27.198 jiwa (BPS, 2014). Selama ini lereng dan lembah Gunung Merapi diketahui banyak memiliki potensi sumberdaya alam berupa sumberdaya air (Santosa, 2006: 1; Sutikno dkk, 2007: 39-51), sumberdaya lahan, sumberdaya mineral, dan sumberdaya hayati (Sutikno dkk, 2007: 51-61). Kondisi sumberdaya air yang melimpah ini mendorong banyak penduduk untuk bertempat tinggal di sekitar lereng dan lembah vulkan. Wilayah sekitar Gunung Merapi telah lama ditempati oleh penduduk untuk menjalankan aktivitas kehidupannya. Kegiatan bercocok tanam yang dilakukan oleh masyarakat telah dilakukan sejak beratus-ratus tahun yang lalu. Kegiatan tersebut melahirkan suatu kebudayaan dan peradaban yang dipertahankan secara turun temurun serta masih berkembang hingga saat ini.

Disamping memiliki potensi sumberdaya alam, Gunung Merapi juga menyimpan potensi bencana yang cukup besar (Sutikno dkk, 2007: 20-30). Aktivitas vulkanik Gunung Merapi menimbulkan ancaman bencana yang harus dihadapi oeh masyarakat. Pada wilayah lembah antar gunungapi Merapi-Merbabu yang mencakup Kecamatan Selo ancaman bahaya ini relatif tinggi (Nurhadi dkk, 2014: 38; Nurhadi dkk, 2015: 75). Pada saat ini masyarakat relatif merasa aman terhadap ancaman bahaya erupsi karena wilayah ini telah lama tidak terkena dampak erupsi yang hebat. Pada masa lampau dampak erupsi umumnya mengarah ke barat daya atau selatan. Namun demikian sejarah erupsi juga mencatat pernah terjadi letusan yang mengarah ke utara yaitu pada tahun 1954-1956 (Andreastuti dkk, 2006: 202).

Berdasarkan konsep geomorfologi "hukum dan proses fisis yang berlaku pada saat ini, berlangsung pula sepanjang waktu geologi walaupun intensitasnya tidak selalu sama dengan saat ini" (Thornbury, 1969: 16 dalam Pramono dan Ashari 2014: 10), maka masih terdapat kemungkinan letusan Gunung Merapi yang pernah terjadi mengarah ke lereng utara dapat terjadi kembali. Ashari (2013) menjelaskan bahwa berdasarkan konsep ini proses alami yang pernah terjadi di masa lalu memungkinkan untuk kembali terjadi pada masa mendatang, sehingga masih terdapat ancaman bahaya yang perlu diwaspadai. Disisi lain Kecamatan Selo saat ini termasuk pusat konsentrasi penduduk dengan jumlah penduduk yang cukup besar. 
Berdasarkan latar belakang tersebut, penelitian ini bertujuan untuk mengkaji distribusi fasies gunungapi di Kecamatan Selo sebagai salah satu cara untuk mengidentifikasi jenis bahaya erupsi Gunung Merapi yang pernah terjadi. Fasies merupakan sejumlah ciri litologi dan paleontologi yang ditunjukkan oleh suatu endapan pada suatu lokasi tertentu (Schieferdecker, 1959 dalam Bronto, 2006: 60). Jenis-jenis fasies Gunungapi menurut Bronto (2006: 60) terdiri dari fasies sentral, piroksimal, medial dan distal. Berdasarkan pengamatan terhadap proses dan produk erupsi Gunungapi aktif masa kini maka, jenis-jenis bahaya gunungapi dapat diidentifikasi. Hal ini sesuai keterangan yang dijelaskan oleh Bronto(2006: 67) yaitu pada fasies sentral dan piroksimal jenis bahaya berupa lontaran batu pijar (bom atau block gunungapi), hujan abu, gas beracun, awan panas (aliran piroklastik), aliran lava dan guguran kubah lava; padafasies medial jenis bahaya berupa awan panas, hujan abu, aliran lahar.; dan pada fasies distal berupa hujan abu, aliran lahar, dan banjir.Informasi mengenai identifikasi fasies dan jenis bahaya bencana, menjadi sangat penting untuk masyarakat sebagai salah satu referensi untuk perencanaan mitigasi bencana.

\section{METODE}

Penelitian ini menggunakan metode deskriptif-eksploratif. Metode eksploratif digunakan untuk mendapatkan data secara langsung dan mendalam dari tempat yang alamiah. Populasi dalam penelitian ini adalah seluruh lahan di Kecamatan Selo. Populasi sasaran yaitu kondisi fisik lahan yang pernah terlanda dan kondisi fisik lahan yang diduga mungkin terlanda. Penentuan sampel fisik yaitu seluruh singkapan batuan yang di daerah penelitian. Pada tahap eksplorasi diperoleh 60 titik lokasi sebagai sampel (Gambar 1). Teknik pengambilan sampel fisik menggunakan teknif purposive sampling. 


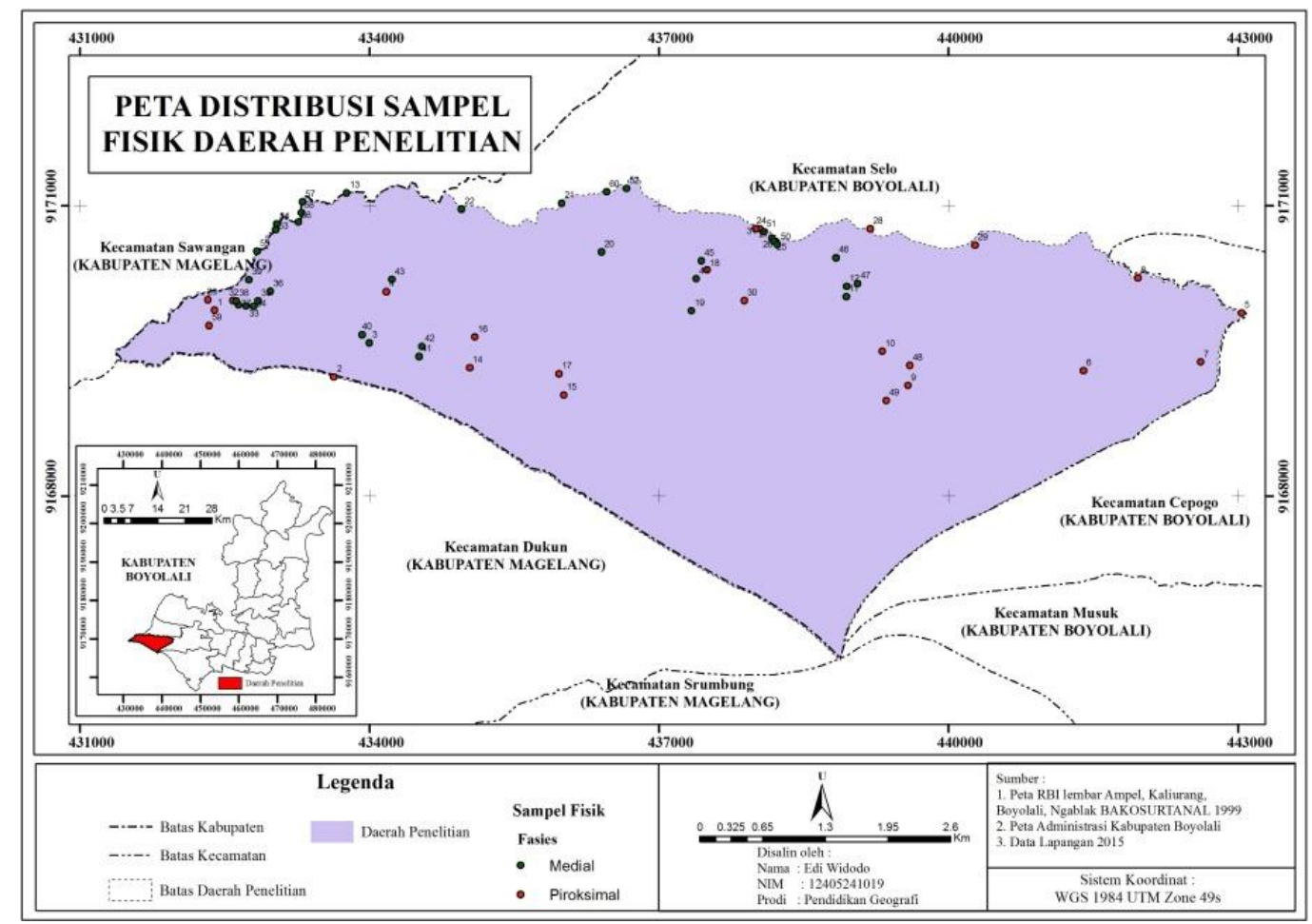

Gambar 1. Peta Distribusi Sampel

Data yang dikumpulkan meliputi bentuklahan, kemiringan lereng, proses geomorfologi, tipe dan produk erupsi, serta stratigrafi endapan Gunungapi Merapi. Metode pengumpulan data yang digunakan adalah observasi, interpretasi citra penginderaan jauh, studi pustaka dan dokumentasi. Jenis data dan metode pengumpulan data ini digunakan oleh Ashari (2013: 131) dengan memperhatikan keterangan dari Bronto (2006: 3) bahwa fasis gunungapi dapat diidentifikasi berdasarkan data inderaja dan geomorfologi, stratigrafi batuan gunungapi, vulanologi fisik, struktur geologi, dan petrologi-geokimia. Analisis dalam penelitian ini menggunakan analisis deskriptif. Identifikasi fasies dengan analisis aspek geomorfologi dilakukan dengan cara matching kondisi morfologi lapangan dengan keterangan fasies dari Bronto (2006: 3-4).

\section{HASIL DAN PEMBAHASAN}

\section{Daerah Penelitian}

Secara astronomis Kecamatan Selo terletak pada antara $110^{\circ} 23^{\prime}-110^{\circ} 30^{\prime}$ BT dan $7^{\circ} 27^{\prime}-7^{\circ} 32^{\prime}$ LS. Secara administratif Kecamatan Selo merupakan salah satu kecamatan yang berada di Kabupaten Boyolali Provinsi Jawa Tengah. Kecamatan Selo di sebelah utara berbatasan dengan Kabupaten Magelang dan Kecamatan Ngampel, Kabupaten Boyolali; di sebelah timur berbatasan dengan Kecamatan Cepogo dan Kecamatan Ngampel Kabupaten Boyolali; di sebelah selatan berbatasan dengan Daerah Istimewa Yogyakarta; dan di sebelah barat berbatasan dengan Kabupaten Magelang (Gambar 2). Kecamatan Selo terdiri dari 10 desa yang tersebar di sisi sebelah timur dan utara lereng Gunung Merapi dengan luas wilayah 5.607,80 km² (Tabel 1). Kecamatan Selo memiliki curah hujan mencapai $3.055 \mathrm{~mm}$ per tahun dengan hari hujan 106 hari. Daerah 
ini memiliki iklim tipe $\mathrm{C}$ berdasarkan pembagian iklim menurut Schmidt dan ferguson. Kecamatan Selo bagian timur dan utara merupakan daerah bayangan hujan,sedangkan disebelah barat dan barat daya memiliki intensitas hujan yang lebih tinggi.

Tabel 1. Pembagian Wilayah Administrasi Kecamatan Selo

\begin{tabular}{|c|l|c|}
\hline No & \multicolumn{1}{|c|}{ Desa } & Luas Wilayah (ha) \\
\hline 1 & Tlogolele & 585,40 \\
\hline 2 & Klakah & 626,10 \\
\hline 3 & Jrakah & 745,70 \\
\hline 4 & Lencoh & 416,70 \\
\hline 5 & Suroteleng & 463,10 \\
\hline 6 & Samiran & 407,90 \\
\hline 7 & Selo & 311,80 \\
\hline 8 & Tarubatang & 380,40 \\
\hline 9 & Senden & 351,10 \\
\hline 10 & Jeruk & $1.319,60$ \\
\hline Jumlah & $5.607,80$ \\
\hline
\end{tabular}

Sumber: pengolahan data sekunder

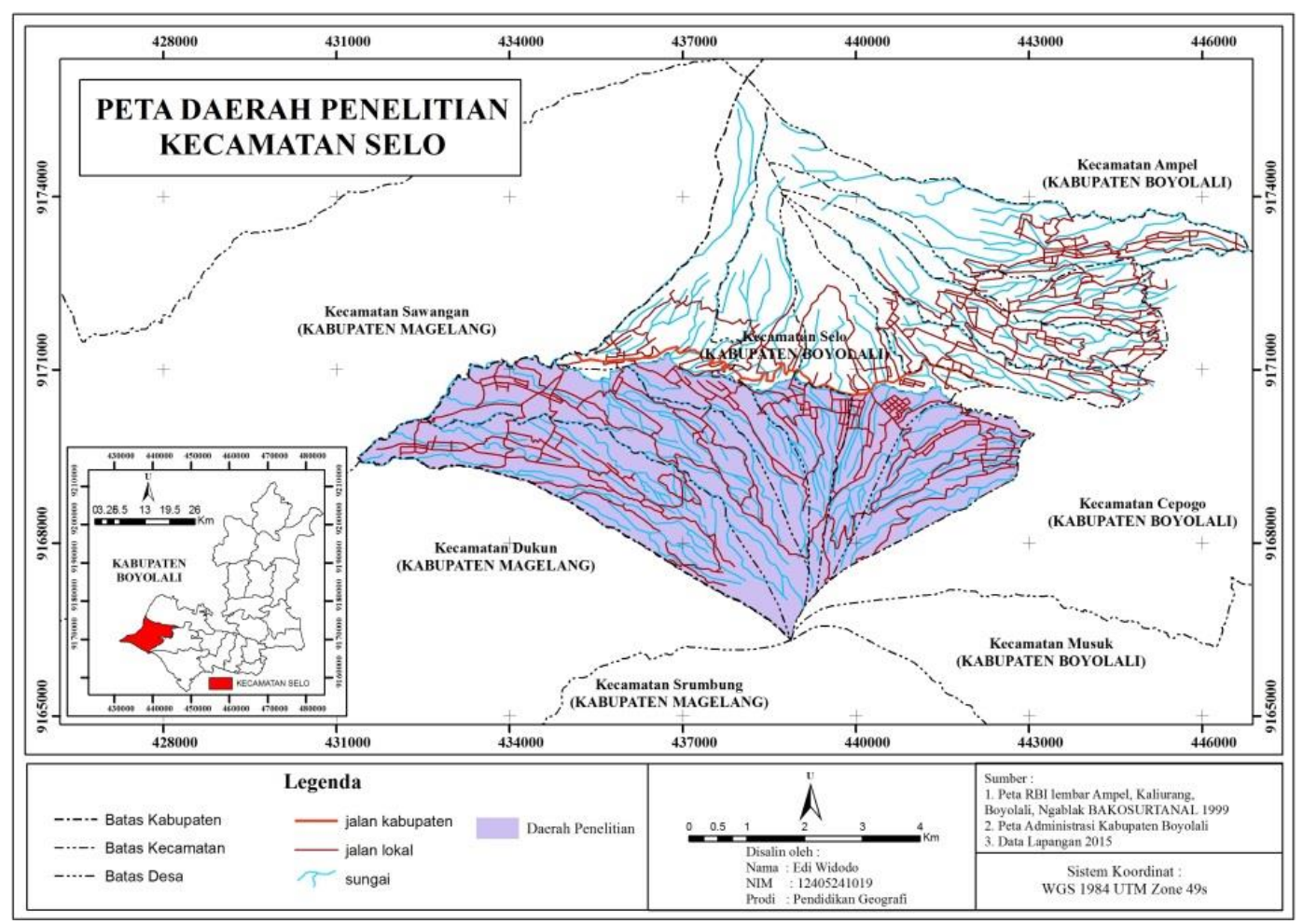

Gambar 2. Peta Administratif Daerah Penelitian

Kecamatan Selo memiliki kemiringan lereng yang sangat beragam mulai dari kondisi miring, agak curam sampai sangat curam. Tidak dijumpai tingkat kemiringan yang landai ataupun datar di Kecamatan Selo, hal ini dipengaruhi kondisi morfologi 
Gunungapi.Kecamatan Selo yang berada diantara lereng Gunung Merapi dan Gunung Merbabu mempunyai ketinggian dari permukaan air laut antara 900 mdpal hingga 2.900 mdpal. Bentuk lahan pada Kecamatan Selo merupakan bentuk lahan asal vulkanik yangterbentuk oleh proses vulkanisme Gunung Merbabu dan Gunung Merapi. Bentuk lahan di Kecamatan Selo meliputi kaki Gunungapi, lereng Gunungapi, Lembah Gunungapi dan Kerucut Gunungapi.

Secara geologis Kecamatan Selo tersusun oleh batuan hasil kegiatan Gunungapi Merbabu dan Gunungapi Merapi. Hasil aktivitas vulkanik Merbabu berada pada Kecamatan Selo bagian utara.Hasil aktivitas vulkanik Merapi meliputi wilayah yang lebih luas dan lebih bervariasi. Penggunaan lahan di Kecamatan Selo dibagi menjadi dua jenis yaitu penggunaan lahan untuk tanah sawah dan tanah kering.

\section{Distribusi fasies Gunung Merapi di Kecamatan Selo Kabupaten Boyolali}

Fasies gunungapi di Kecamatan Selo terdiri dari fasies sentral, fasies piroksimal, dan fasies medial (Gambar 3). Fasies piroksimal mendominasi daerah penelitian dan terdapat di seluruh desa di daerah penelitian. Fasies medial meliputi wilayah yang lebih sempit daripada fasies piroksimal, dijumpai di beberapa desa. Adapun fasies sentral hanya menempati wilayah yang relatif sempit yaitu di sekitar kepundan gunungapi.

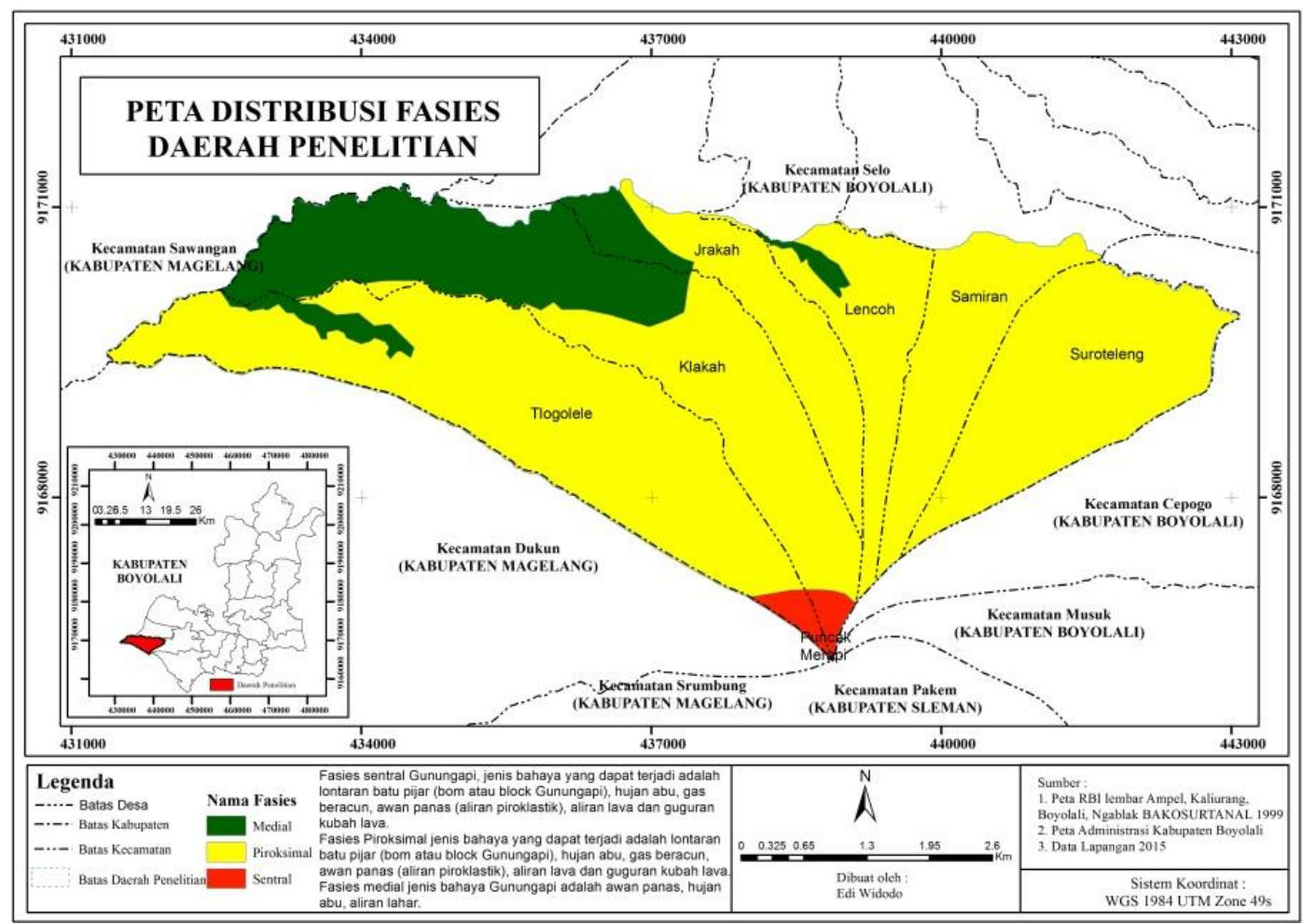

Gambar 3. Peta Distribusi Fasies Gunungapi pada lereng utara Gunungapi Merapi Kecamatan Selo 
Fasies Sentral memiliki luas \pm 39 ha,dijumpai di sekitar kepundan Gunungapi Merapi, yang dicirikan oleh asosiasi batuan beku pada kubah lava.Hal ini sesuai dengan pendapat Bronto (2006) yang menjelaskan bahwa fasies sentral merupakan tempat keluarnya magma, sehingga daerah ini dicirikan oleh asosiasi batuan beku berupa kubah lava dan berbagai macam batuan terobosan semi gunungapi. Berdasarkan geomorfologi fasies sentral terdapat di sekitar puncak gunungapi. Contoh kenampakan batuan penciri fasies sentral yang dijumpai di daerah penelitian ditunjukkan oleh Gambar 4.

Fasies Piroksimal di Kecamatan Selo memiliki luas $\pm 2.228 \mathrm{Ha}$, kawasan ini terletak paling dekat dengan sumber erupsi atau fasies sentral. Kenampakan fasies piroksimal di yang dijumpai di daerah penelitian dicirikan oleh asosiasi batuan pada kerucut Gunungapi komposit yang didominasi oleh perselingan aliran lava dan breksi piroklastik. Sampel pengamatan diambil di Desa Jrakah. Pada sampel ini dijumpai endapan lava dan piroklastik. Material lava tersingkap akibat adanya erosi di dasar sungai (Gambar 5a). Material piroklastik tersingkap akibat adanya gerakan massa berupa longsor (Gambar 5b). Material lava dan piroklastik ditemukan pada lokasi yang sama. Endapan piroklastik ini termasuk dalam jenis endapan piroklastik aliran. Hal ini di cirikan dengan sebarannya dipengaruhi oleh morfologi, batas bawah dibatasi oleh area berupa endapan letusan Gunungapi yang berbeda proses atau berbeda material penyusunnya dan pada bagian atas relatif datar serta pada umumnya mempunyai struktur masif. Contoh lain material penciri fasies piroksimal yang berupa endapan piroklastik dijumpai di Desa Tlogolele. Singkapan material endapan piroklastik dijumpai di permukaanoleh aktivitas manusia berupa penambangan pasir dan batu. Endapan piroklastik ini termasuk dalam jenis endapan piroklastik jatuhan. Hal ini di cirikan dengan struktur butiran bersusun dan endapan berlapis naik. Material ini memiliki ketebalan dua sampai tiga meter.

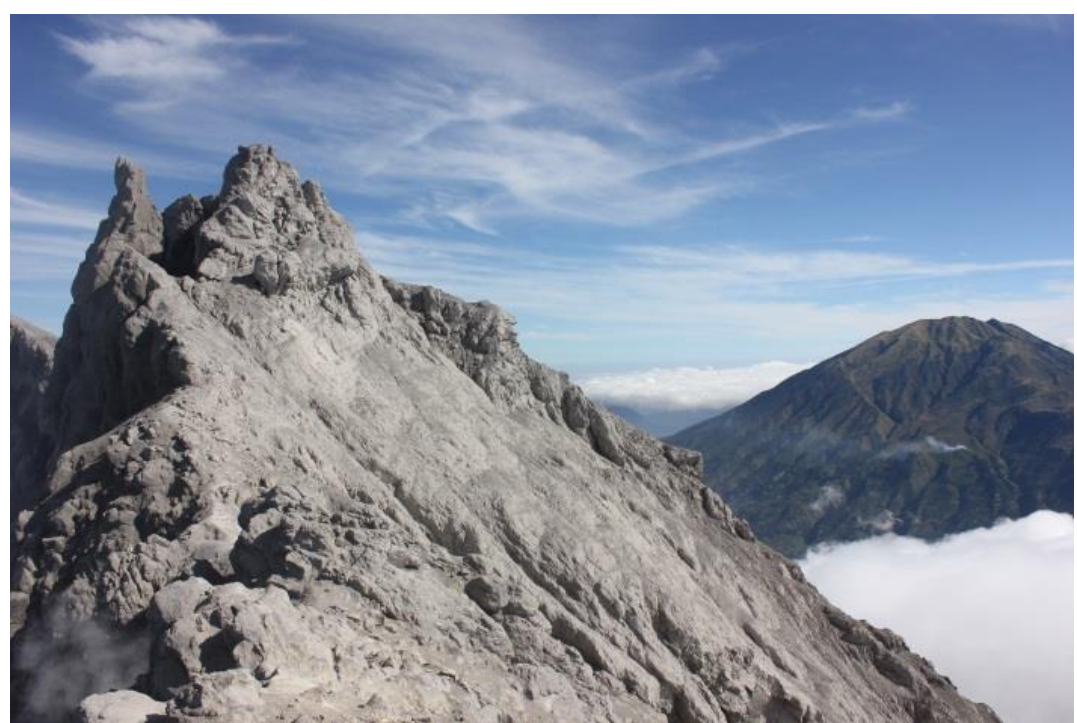

Gambar 4. Kenampakan batuan pada fasies sentral Gunungapi Merapi 

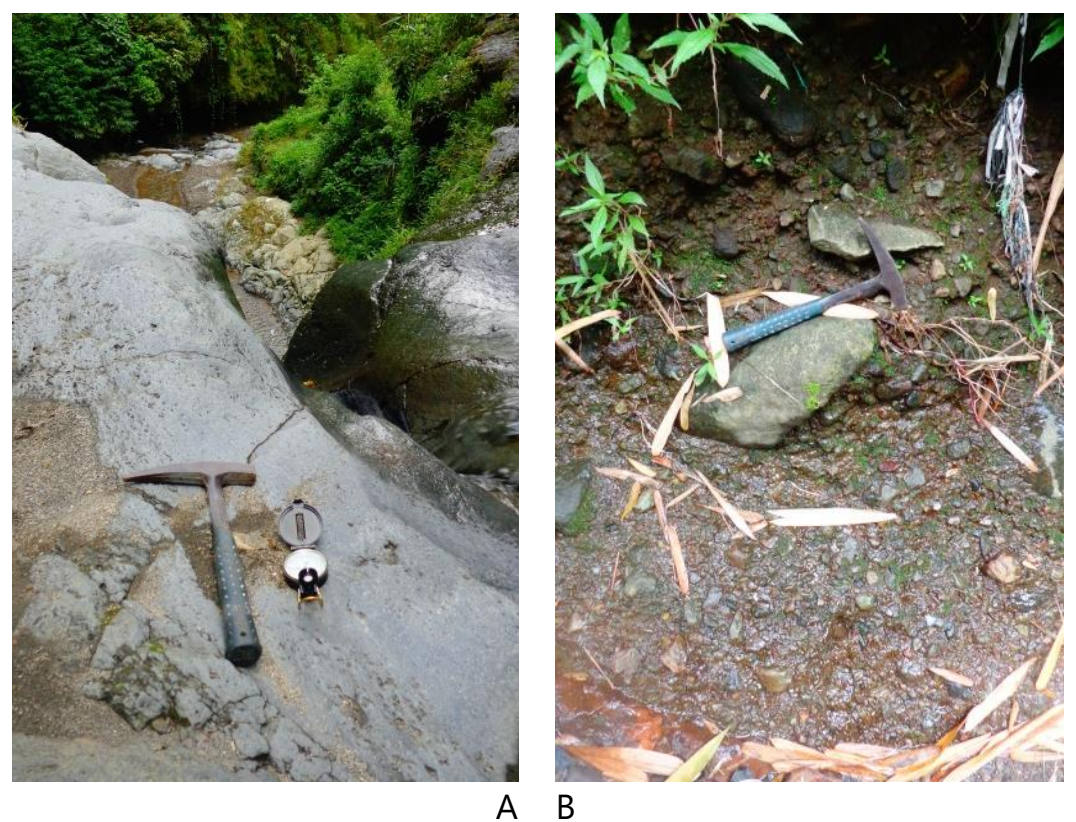

Gambar 5. A. Endapan lava, B Endapan piroklastik,pada fasies piroksimal di Desa Jrakah, lokasi 438075 MT dan 9170775 MU pada zona 49S UTM (Data Lapangan, 2013)

Fasies Medial memiliki luas $\pm 483 \mathrm{Ha}$, kawasan ini didominasi batuan breksi piroklastik dan tuff serta breksi lahar yang sudah mulai berkembang. Salah satu contoh sampel menunjukan kenampakan batuan lahar yang mendominasi sepanjang singkapan (Gambar 6). Ciri batuan lahar di lokasi sampel yaitu diameter batuan setengah sampai dua meter, hampir membulat, dan bertekstur halus. Ashari (2013) juga menjumpai material yang sama pada fasies medial lereng barat Gunungapi Merapi yaitu berupa endapan bersortasi buruk, ukuran butir bervariasi, beberapa diantaranya memiliki diameter lebih dari 1 meter dan bersisi membulat. Sampel pengamatan fasies medial diambil di Desa Klakah. Sampel ini terdapat singkapan berupa lahar. Singkapan ini terjadi akibat adanya gerakan massa (longsor) dan erosi lahan. Endapan lahar ini memiliki ketebalan sekitar empat sampai lima meter dengan diameter batuan ada yang lebih dari satu meter. Lapisan endapan material lahar ini yang tersingkap memiliki dua dan tiga lapisan. 


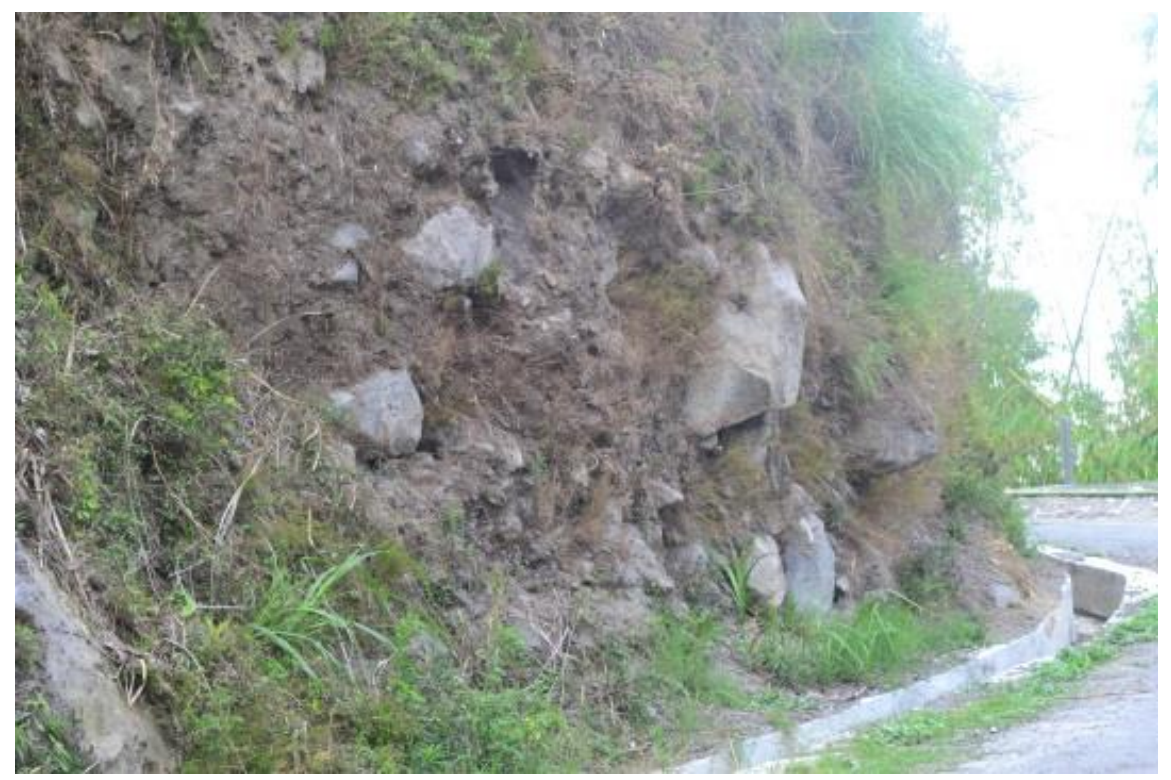

Gambar 6. Endapan lahar pada fasies Medial di Desa Jrakah, lokasi 437337 MTdan 9169915 MU pada zona 49S UTM (Data Lapangan, 2013)

Berdasarkan wilayah administratif desa, Desa Suroteleng dan Desa Samiran secara keseluruhan berada pada fasies Piroksimal. Kemudian Desa Lencoh dan Desa Jrakah berada pada zona fasies Piroksimal dan Medial. Fasies Piroksimal tetap mendominasi dibandingkan fasies Medial di Desa Lencoh dan Desa Jrakah. Desa Klakah dan Desa Tlogolele memiliki tiga zonasi fasies yaitu fasies Sentral pada bagian puncak Gunungapi Merapi, fasies Piroksimal berada diantara fasies Sentral dan fasies Medial yang masih mendominasi distribusi fasies, kemudian fasies Medial yang luasan sebarannya Desa Klakah lebih luas dibandingkan Desa Tlogolele. Distribusi fasies pada daerah penelitian menunjukkan bahwa fasies Piroksimal sebarannya paling luas dibandingkan fasies Sentral dan fasies Medial.

\section{Jenis Bahaya Erupsi di Kecamatan Selo berdasarkan Distribusi Fasies Gunungapi}

Pengamatan proses dan produksi erupsi yang dilakukan pada setiap fasies gunungapi di Kecamatan Selo dapat digunakan untuk memperkirakanjenis bahaya yang mengancam. Hal ini didasarkan pada konsep dasar geomorfologi yang menyatakan bahwa proses geomorfologi yang berlangsung pada saat ini juga berlangsung sepanjang kurun waktu geologi walaupun dengan intensitas yang tidak selalu sama dengan saat ini. Dengan demikian jenis material produk erupsi yang terjadi pada masa lampau dapat menjadi indikator jenis ancaman yang terdapat pada wilayah tersebut.

Fasies sentral Gunungapi sebagai pusat erupsi memiliki jenis bahaya yang paling beragam. Berdasarkan karakteristik material hasil erupsi yang dijumpai di daerah penelitian, fasies sentral memiliki potensi bahaya berupa Iontaran batu pijar (bom atau block Gunungapi), hujan abu, gas beracun, awan panas (aliran piroklastik), aliran lava dan guguran kubah lava. Fasies sentral secara administrasi termasuk dalam Desa Klakah dan 
Desa Tlogolele, namun demikian karena berada disekitar puncak Gunungapi Merapi, lokasi ini tidak dihuni penduduk sehingga ancaman bahaya di wilayah ini tidak secara langsung mengancam kehidupan masyarakat.

Pada fasies piroksimal, jenis bahaya yang dapat terjadi antara lain berupa lontaran batu pijar (bom atau block Gunungapi), hujan abu, gas beracun, awan panas (aliran piroklastik), aliran lava dan guguran kubah lava. Fasies piroksimal mendominasi sebaran fasies Pada daerah penelitian Kecamatan Selo baik pada daerah permukiman, tempat aktivitas penduduk seperti lahan pertanian, perkebunan dan hutan yang dikelola masyarakat. Adapun pada fasies medial jenis bahaya gunungapi yang menjadi ancaman adalah awan panas, hujan abu, aliran lahar. Fasies medial terdapat pada Desa Lencoh, Desa Jrakah, Desa Klakah dan Desa Tlogolele Kecamatan Selo, lokasi ini juga termasuk dalam jangkauan aktivitas manusia baik permukiman, lahan pertanian, dan hutan yang dikelola masyarakat.

\section{SIMPULAN}

Distribusi fasies di Kecamatan Selo yaitu fasies Sentral, fasies Piroksimal dan fasies Medial. Fasies Piroksimal mendominasi luasan distribusi dibandingkan fasies Sentral dan fasies Medial. jenis bahaya erupsi pada fasies sentral dan piroksimal berupa aliran lava, aliran piroklastik, dan jatuhan piroklastik, sedangkan pada fasies medial berupa aliran piroklastik dan lahar. Upaya mitigasi yang dapat dilakukan yaitu mitigasi bencana struktural yaitu perlu membangun fasilitas umum di tempat titik kumpul sementara, menyediakan tempat pengungsian bagi warga dan ternak warga yang aman, membangun jembatan gantung yang kuat yang menghubungkan setiap dusun dan arahan mitigasi bencana secara non struktural yaitu peningkatan kesiapsiagaan penduduk dan memperbaiki fungsi organisasi penanggulangan bencana di Kecamatan Selo.

\section{UCAPAN TERIMA KASIH}

Tulisan ini merupakan bagian dari penelitian tugas akhir skripsi Pendidikan Geografi, Fakultas IImu Sosial, Universitas Negeri Yogyakarta yang berjudul Distribusi Fasies Gunung Merapi Untuk Mitigasi Bencana Erupsi Di Kecamatan Selo Kabupaten Boyolali. Dalam kesempatan ini penulis mengucapkan terima kasih yang sebesar-besarnya kepada berbagai pihak yang telah membantu dalam proses penelitian, khususnya kepada Bapak Drs. Heru Pramono, SU selaku pembimbing tugas akhir.

\section{DAFTAR PUSTAKA}

Andreastuti, S,D., Newhall, C., dan Dwiyanto, J. 2006. Menelusuri Kebenaran Letusan Gunung Merapi 1006. Jurnal Geologi Indonesia 1 (4): 201-207.

Ashari, A. 2013. Kajian Fasies Gunungapi di Kompleks Candi Asu untuk Pendugaan Bencana Erupsi Merapi. Socia 10 (2): 129-138

BPS. 2014.data Kecamatan Selo Dalam Angka Tahun 2014.

Bronto, S. 2006. Fasies Gunungapi dan Aplikasinya. Jurnal Geologi Indonesia 1 (2): 59-71.

Nurhadi., Ashari, A., dan Suparmini. 2014. Kajian Risiko Bencana pada Lembah Antar Gunungapi Merapi-Merbabu Jawa Tengah. Laporan Penelitian. LPPM UNY. 
Nurhadi., Ashari, A., dan Suparmini. 2015. Kajian Bahaya Erupsi dan Longsor pada Lembah Antar Gunungapi Merapi-Merbabu Jawa Tengah. Jurnal Penelitian Saintek 20 (1): 74-88.

Santosa, L.W. 2006. Kajian Hidrogeomorfologi Mataair di Sebagian Lereng Barat Gunungapi Lawu. Forum Geografi20 (1): 68-85.

Sutikno., Santosa, L.W., Widiyanto., Kurniawan, A., dan Purwanto, T.H. 2007. "Kerajaan Merapi" Sumberdaya Alam dan Daya Dukungnya. Yogyakarta: BPFG UGM. 